\title{
BERTAHAN USAHA PADA UMKM DI TENGAH PANDEMIC COVID-19
}

\author{
${ }^{1 *}$ Darwis Agustriyana, ${ }^{2}$ Nabilah Ramadhan, ${ }^{3}$ Shinta Oktavien, \\ ${ }^{4}$ Rd.Herman Sofyandi \\ Universitas Widyatama \\ Email : ${ }^{1}$ darwis.agustriyana@widyatama.ac.id
}

Manuskrip: Sept-2020; Ditinjau: Okt-2020; Diterima: Okt-2020;

Online: Jan-2021; Diterbitkan: Jan-2021

\begin{abstract}
ABSTRAK
UMKM mempunyai peran yang sangat penting dalam menggerakkan roda perekonomian Jawa Barat. Oleh sebab itu, aktivitas UMKM merupakan kegiatan ekonomi yang tidak dapat dipisahkan dalam kehidupan masyarakat dalam mencukupi kebutuhan hidup. Meskipun demikian, seiring dengan semakin meluasnya pandemic wabah virus Covid-19 mengakibatkan banyak para pelaku usaha yang kesulitan dalam menjalankan aktivitas bisnisnya, tanpa terkecuali para pelaku UMKM yang mendapatkan dampak yang cukup tinggi. Yang menjadi tujuan diadakannya kegiatan Pengabdian kepada Masyarakat ini adalah untuk menjaga semangat berwirausaha bagi UMKM di Jawa Barat dalam menghadapi masa sulit selama pandemic covid-19 serta membentuk dan memberikan pengarahan dalam menyusun strategi bertahan bagi UMKM yang terdampak covid-19. Metode pelaksanaan kegiatan ini adalah ceramah dengan menggunakan media daring (online) melalui youtube live dengan menghadirkan narasumber dari unsur pemerintah dan praktisi serta akademisi. Target materi pada kegiatan Pengabdian kepada Masayarakat ini tercapai dengan cukup baik dengan ketercapaian target jumlah peserta, tujuan kegiatan, serta ketercapaian target materi yang telah direncanakan yakni pembahasan mengenai situasi yang terjadi saat ini pada UMKM dengan merebaknya wabah virus Covid-19, serta inovasi dan strategi yang dapat dilakukan para pelaku UMKM untuk bertahan di tengah kondisi pandemic Covid19.
\end{abstract}

\section{Kata Kunci : UMKM, Sumber Daya Manusia, Inovasi}

\section{PENDAHULUAN}

Usaha Mikro, Kecil, dan Menengah (UMKM) merupakan salah satu bidang usaha yang dapat berkembang dan konsisten dalam perekonomian nasional. UMKM menjadi wadah yang baik bagi penciptaan lapangan pekerjaan yang produktif. Hal ini dikarenakan UMKM merupakan usaha yang bersifat padat karya dan tidak membutuhkan persyaratan tertentu seperti tingkat pendidikan dan keahlian (keterampilan) pekerja. Usaha skala kecil di Indonesia menyerap sekitar 97\% tenaga kerja (Data dari Kementerian Koperasi dan Usaha Kecil dan Menengah 2019). Ini berarti tenaga kerja di Indonesia bekerja sebagian besar 
bekerja di sektor UMKM dan sisanya sekitar 3\% saja yang bekerja di sektor usaha besar.

Kontribusinya yang besar terhadap penyerapan tenaga kerja menunjukkan bahwa UMKM mempunyai peran penting di dalam pembangunan dan pertumbuhan ekonomi baik di negara berkembang maupun di negara maju. UMKM berkontribusi terhadap pembentukan dan pertumbuhan Produk Domestik Bruto (PDB) paling besar dibandingkan kontribusinya dari usaha besar (Tambunan, 2012).

Sampai dengan saat ini, dunia usaha di Jawa Barat masih didominasi oleh Usaha Mikro Kecil (UMK) yang jumlah usahanya mencapai lebih dari 4,5 juta usaha atau 98,84 persen dari total usaha non-pertanian di Jawa Barat dengan kemampuan menyerap tenaga kerja Jawa Barat sebanyak lebih dari 9,7 juta orang atau sekitar 74,07 persen dari total tenaga kerja non pertanian. Oleh sebab itu, UMK mempunyai peran yang sangat penting dalam menggerakkan roda perekonomian Jawa Barat. Pengelolaan usaha ini dilakukan secara sederhana sehingga lebih banyak menjadi pilihan sebagai wadah usaha yang menghasilkan nilai ekonomi. Usaha ini bisa menjadi pilihan utama karena tidak perlu mengeluarkan modal yang cukup besar untuk memulainya.

Pada bulan Maret 2020, hadirlah sebuah virus yang kehadirannya mengganggu tatanan yang sudah berjalan, khususnya dalam hal ekonomi, yakni corona virus jenis baru yang disebut COVID-19 Virus ini pertama kali ditemukan di kota Wuhan, China pada akhir Desember 2019. Virus ini menular dengan sangat cepat dan telah menyebar ke hampir semua negara, termasuk Indonesia, hanya dalam waktu beberapa bulan. Bahkan COVID-19 ini sekarang telah menjadi sebuah pandemi yang terjadi di hampir seluruh negara di seluruh dunia. Hal tersebut membuat beberapa negara menerapkan kebijakan untuk memberlakukan lockdown dalam rangka mencegah penyebaran virus Corona. Di Indonesia sendiri, khususnya di Jawa Barat, diberlakukan kebijakan Pembatasan Sosial Berskala Besar (PSBB) untuk menekan penyebaran virus ini.

Seiring dengan semakin meluasnya pandemic wabah virus Covid-19 mengakibatkan perekonomian Jawa Barat menjadi terpuruk dengan mengalami kontraksi minus 5,90. Oleh sebab itu, pemulihan ekonomi pun dilakukan secara komprehensif dan melibatkan banyak pihak. Ketahanan pangan dan usaha mikro, kecil, dan menengah (UMKM) menjadi sektor yang dikedepankan untuk pemulihan. Sebab, pemulihan dua sektor tersebut akan berdampak langsung terhadap daya beli masyarakat yang sempat melesu selama pandemi. Selain itu, pelaku UMKM pun menjadi pihak yang paling dirugikan dengan mewabahnya pandemic wabah virus Covid-19 di Indonesia, terutama di Jawa Barat.

Sebanyak 37.119 usaha mikro kecil dan menengah (UMKM) di Jawa Barat terkena dampak pandemi Covid-19 sehingga produksi menurun dan bahkan sebagian terpaksa berhenti beroperasi. Berdasarkan data dari Dinas Koperasi dan Usaha Kecil Provinsi Jawa Barat, setelah dilaksanakan survei pada bulan April atau satu bulan setelah kasus positif pertama Covid-19 di Indonesia diumumkan oleh Presiden RI pada 2 Maret 2020, 97 persen UMKM menurun produksinya dan 40 
persen di antaranya berhenti beroperasi. Hanya tiga persen yang meningkat. Data tersebut menunjukan bahwa kondisi krisis akibat wabah Covid-19 saat ini berbeda dengan krisis ekonomi yang melanda Indonesia pada 1998. Saat Indonesia mengalami krisis moneter 1998, UMKM menjadi penyangga ekonomi nasional. Menyerap tenaga kerja, dan menggerakan perekonomian. Sementara 2008 di masa krisis keuangan global, UMKM tetap kuat menopang perekonomian. Tetapi berbeda halnya dengan penyebaran virus Covid-19 ini. Sektor UMKM lah yang paling terkena dampak dari virus ini.

Terdapat 3 tantangan utama yang dihadapi pelaku UMKM selama pandemi Covid-19 mewabah di tanah air. Pertama adalah dari segi pasokan. Semenjak diberlakukannya Pembatasan Sosial Berskala Besar (PSSB) hampir di seluruh wilayah, banyak para UMKM mengalami kesulitan untuk mendapatkan bahan baku. PSBB membuat distribusi logistik juga ikut terganggu yang membuat barang kiriman yang dipesan atau yang dibeli menjadi lama diterima. Tantangan Kedua adalah masalah cashflow. Banyak pelaku UMKM yang merasakan pendapatannya menurun akibat tidak adanya pelanggan yang membeli produk semenjak PSBB dan physical distancing diberlakukan. Selain itu, para pelaku UMKM juga kesulitan mendapatkan pinjaman modal. Sudah pendapatan menurun, biaya untuk produksi sedikit mahal, ditambah lagi sulitnya akses peminjaman modal yang membuat cashflow UMKM menjadi terganggu. Tantangan ketiga yakni dari anjloknya permintaan. Ketidakpastian pasar membuat permintaan akan barang yang dijual oleh para UMKM menjadi berpengaruh. Apalagi semenjak ada pandemi membuat kebutuhan para konsumen berubah. Masyarakat saat ini lebih membutuhkan produk-produk kesehatan seperti hand sanitizer dan masker dibandingkan kebutuhan lainnya.

Perubahan adalah hal yang pasti terjadi, termasuk di dalam konteks organisasi. Perubahan terjadi karena yang menjalankan organisasi adalah manusia, dan manusia terus berubah. Sering dikatakan satu hal yang pasti terjadi di dunia adalah perubahan. Perubahan adalah suatu proses dimana terjadinya peralihan atau perpindahan dari status tetap (statis) menjadi status yang bersifat dinamis.

Menurut Robbins (2013), perubahan organisasi adalah tindakan beralihnya sesuatu organisasi dari kondisi yang berlaku kini menuju ke kondisi masa yang akan datang menurut yang di inginkan guna meningkatkan efektivitasnya. Perubahan organisasi dapat didorong oleh pengaruh yang ditimbulkan dari lingkungan internal dan eksternal organisasi. Lingkungan internal mempengaruhi organisasi terhadap cara organisasi melaksanakan kegiatan-kegiatannya. Lingkungan eksternal mempengaruhi organisasi terhadap kemampuan organisasi untuk memperoleh sumber daya-sumber daya yang dibutuhkan untuk memproduksi dan memasarkan berbagai produk.

Pandemic covid-19 termasuk ke dalam lingkungan eksternal organisasi yang mendorong organisasi untuk segera melakukan perubahan agar tetap bertahan dan berkembang. Adaptasi yang lebih maju pada saat sulit seperti saat ini adalah dengan melakukan berbagai inovasi, yakni suatu tindakan kreatif yang sistematis, terencana dengan proyeksi masa depan, dan ukuran supply demand. Bahkan inovasi 
tetap dilakukan meski tanpa demand saat ini atau suatu saat nanti, karena keyakinan bahwa supply akan menciptakan demand. Inovasi didorong oleh kemampuan untuk melihat koneksi, menangkap peluang dan untuk mengambil keuntungan dari mereka.

Menurut Bessant dan Tidd (2011), inovasi ada empat bentuk, yaitu inovasi produk, proses, posisi dan paradigma. Inovasi produk berkenaan dengan penawaran produk baru ke pasar. Inovasi proses, berkaitan dengan pembaruan dalam cara membuat dan menyampaikan produk dan jasa, sedangkan inovasi posisi adalah perubahan dalam cara memperkenal produk dan jasa. Adapun inovasi paradigma berhubungan dengan model mental atau cara pandang yang mendasari organisasi dalam bertindak atau beraktivitas.

Inovasi bisnis dalam situasi pandemi, bagaimanapun harus memperhatikan dua aspek penting yaitu: sumber daya finansial dan pasar. Dari sisi finansial, pandemi secara umum telah menggerus sumberdaya UMKM, seiring dengan penurunan pendapatan mereka. Sumber daya finansial mereka akan lebih banyak digunakan untuk bertahan hidup. Itu artinya, inovasi yang membutuhkan sumberdaya finansial yang besar, seperti peluncuran produk baru sebaiknya dijauhi. Pasar, di sisi lain ditandai dengan melemahnya daya beli dan disertai dengan perubahan preferensi konsumen. Konsumen lebih memilih berbelanja pada barang kebutuhan yang penting dan mendesak, dibandingkan dengan barang kebutuhan yang kurang penting dan mendesak. Sebab itu, inovasi yang dipilih pun bukan hanya selaras dengan sumberdaya, akan tetapi juga aksesibilitas pasar.

Menurut Kepala Dinas Koperasi dan Usaha Kecil Provinsi Jawa Barat, Bapak Kusmana Hartadji, UMKM Jabar punya modal besar untuk bangkit, pertama jumlah penduduk yang besar hampir 50 juta jiwa dan itu merupakan pangsa pasar yang besar dan kedua, gerakan cinta produk dalam negeri saat ini semakin terasa di masyarakat karena saat pandemi seperti saat ini produk impor berkurang, inilah kesempatan bagi produk dalam negeri untuk berkembang dan dikonsumsi oleh masyarakat.

\section{METODE PELAKSANAAN KEGIATAN}

Dengan adanya wabah covid-19 dan demi memenuhi tuntutan protokol kesehatan selama covid-19, maka metode pelaksanaan kegiatan pengabdian kepada masyarakat kali ini akan menggunakan media daring (online) dengan memanfaatkan beberapa saluran komunikasi seperti youtube live dan zoom. Mengingat kegiatan dilakukan secara virtual sehingga interaksi dengan audiens menjadi terbatas maka materi dan konten dari seminar dan pelatihan ini dibuat sebaik dan semenarik mungkin agar lebih mudah dipahami oleh peserta. Metode kegiatan pengabdian yang digunakan, mayoritas adalah pemaparan dari narasumber, yakni materi mengenai kondisi UMKM di Jawa Barat dan Solusi dari Pemerintah yang disampaikan oleh Sekretaris Dinas Koperasi dan Usaha Kecil Provinsi Jawa Barat, Bapak H.Suhra, S.E.,M.M.,Ak. serta materi mengenai Strategi Bertahan UMKM di Tengah Pandemic Covid-19 oleh Direktur PT.Strabiz Manajemen, Bapak Dr. Meriza Hendri, SIP,, M.M selaku praktisi dan akademisi. 
Setelah pemaparan materi, dilanjutkan dengan sesi tanya jawab oleh akademisi dosen Universitas Widyatama.

\section{HASIL DAN PEMBAHASAN}

Hasil kegiatan PKM secara garis besar terdiri dari ketercapaian target jumlah peserta, ketercapaian tujuan kegiatan, serta ketercapaian target materi yang telah direncanakan. Sebelum kegiatan ini dilaksanakan, terdapat 14 UMKM yang mendaftar menjadi peserta. Namun karena kegiatan ini akhirnya disiarkan melalui youtube live, maka peserta yang mengikuti kegiatan ini pun terdiri dari bermacam kalangan. Total terakhir jumlah views yang didapat adalah 234 views. Hal ini menunjukan ketercapaian jumlah peserta yang telah ditargetkan.

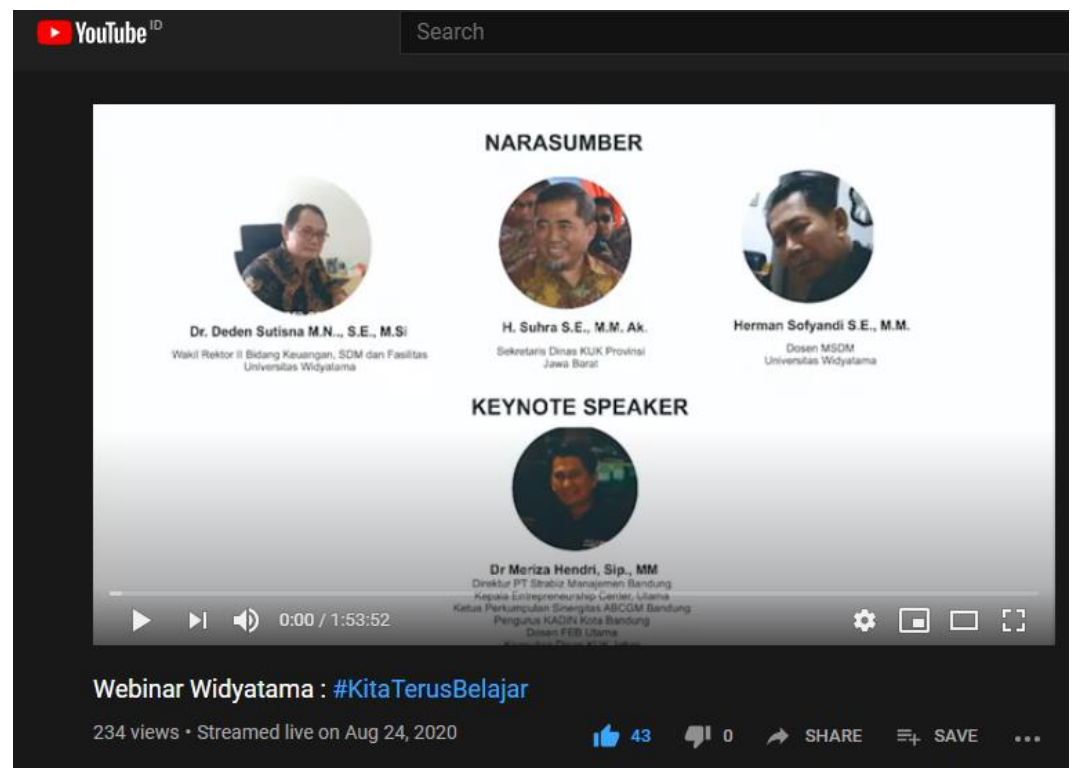

Gambar 1. Jumlah Views Peserta Kegiatan

Tujuan dari kegiatan pengabdian ini adalah untuk menjaga semangat berwirausaha bagi UMKM di Jawa Barat dalam menghadapi masa sulit selama pandemic covid-19 serta membentuk dan memberikan pengarahan dalam menyusun strategi bertahan bagi UMKM yang terdampak covid-19. Ketercapaian tujuan tujuan dari kegiatan pengabdian ini ditunjukkan dengan antusiasme para peserta bertanya dan sharing ilmu selama kegiatan tanya jawab. Selain pertanyaan dari peserta yang sudah terdaftar, terdapat juga komentar dan masukan dari rekan akademisi lain yang menjadi peserta pada kegiatan ini.

Ketercapaian target materi pada kegiatan PKM ini cukup baik karena materi diberikan melalui dua sudut pandang yakni dari lingkup pemerintahan, yang menjabarkan materi mengenai kondisi UMKM Jawa Barat saat ini di tengah pandemic covid-19 serta apa saja peran pemerintah dalam membantu UMKM agar tetap bertahan dan berkembang meskipun menghadapi pandemic covid-19, sudut pandang lainnya diberikan oleh narasumber kedua yakni Bapak Dr. Meriza Hendri, 
SIP, M.M selaku praktisi dan akademisi. Dengan adanya materi dari dua sudut pandang tersebut, diharapkan dapat terjadi transfer knowledge mengenai keadaan UMKM tentang kendala apa yang dihadapi selama menjalankan usahanya dan khususnya kendala yang bertambah ketika terjadinya pandemic covid-19 seperti saat ini serta membahas bagaimana inovasi dan peluang dapat ditangkap dari kondisi pandemic covid-19 ini. Materi yang disampaikan kepada peserta pelatihan telah sesuai dan mudah dipahami, sehingga mitra sangat antusias ketika diadakan sesi diskusi dan bersama-sama mencari strategi bertahan dan inovasi ide peluang usaha baru

Dari empat jenis bentuk inovasi, beberapa layak untuk diterapkan oleh UMKM Jawa Barat di masa krisis Pandemi Covid-19. Contohnya inovasi proses, terkait dengan cara baru penyampaian produk ke konsumen sangat mungkin di lakukan. UMKM dapat menggunakan media online untuk menyampaikan produk mereka ke konsumen. Perusahaan katering pernikahan melakukan inovasi proses dengan menawarkan delivery service yang memungkinkan para tamu undangan menikmati hidangan sambil menyaksikan pernikahan secara daring di rumah. Demikian juga dengan jasa les privat, yang menawarkan model belajar daring.

Inovasi posisi dilakukan manakala perusahaan mengalihkan produk lama mereka ke pasar baru. Dalam inovasi posisi, perusahaan berusaha melakukan penyesuaian agar produk lama mereka dapat diterima di pasar yang baru. Sebagai contoh film yang seharusnya ditayangkan di gedung bioskop, ditawarkan ke jaringan televisi berbayar, ataupun produk kebersihan rumah ditawarkan ke pasar kesehatan. Saat ini banyak dijumpai UMKM di Industri konveksi sebagian mengalihkan produk fashion mereka ke alat pelindung diri (APD), masker dan produk lain terkait dengan perlindungan diri.

\section{KESIMPULAN DAN SARAN}

Mewabahnya pandemi Covid-19 memukul hampir seluruh sektor. Usaha mikro kecil dan menengah (UMKM) menjadi sektor usaha yang merasakan dampak cukup dalam dari pandemi virus corona Covid-19, berbeda dengan krisis tahun 1998 dimana UMKM saat itu justru menjadi pahlawan dalam menggerakkan kembali perekonomian nasional. Perubahan yang terjadi di era pandemic seperti saat ini menjadi satu hal penting yang harus dilakukan setiap organisasi untuk bisa bertahan dan berkembang. UMKM harus mampu beradaptasi dengan perubahan yang terjadi. Adaptasi yang lebih maju pada saat sulit adalah dengan melakukan berbagai inovasi.

Inovasi yang dapat dilakukan UMKM untuk bertahan dan berkembang di era covid-19 ini dapat dilakukan dengan berbagai cara seperti mengubah proses penjualan menjadi online maupun melakukan penyesuaian produk seperti perusahaan konveksi yang beralih menjadi produsen masker di saat pandemic seperti saat ini. Bagi wirausahawan baru, kondisi covid-19 ini dapat menjadi kesempatan untuk memulai bisnis nya dengan mencari peluang-peluang usaha yang muncul di masa pandemic covid-19 seperti usaha warung online, alat-alat kesehatan dan herbal, serta usaha lainnya.. 
Berdasarkan pelaksanaan kegiatan yang telah dilaksanakan, dirasakan perlu dilakukan pemantauan, pendampingan dan pemberian motivasi secara berkesinambungan agar inovasi yang sudah dibuat UMKM dapat diimplementasikan dengan baik sehingga mampu bertahan di tengah pandemic covid-19.

\section{DAFTAR PUSTAKA}

Anggraita Primatami, N. H. (2019). Perkembangan Usaha Mikro Kecil (UMK) Di Provinsi Jawa Barat Tahun 2006 - 2016. Jurnal Pengembangan Wiraswasta, 203-212.

Badan Pusat Statistik Provinsi Jawa Barat. (2017). Provinsi Jawa Barat dalam Angka 2017. Bandung: BPS Provinsi Jawa Barat.

Badan Pusat Statistik Provinsi Jawa Barat. (2018). Potensi Usaha Mikro Kecil Provinsi Jawa Barat. Bandung: BPS Provinsi Jawa Barat.

Bessant, John., dan Joe Tidd. (2011). Innovation and Entrepreneurship. Second Edition. John Wiley \& Sons, Ltd.

Effendy, A., \& Sunarsi, D. (2020). Persepsi Mahasiswa Terhadap Kemampuan Dalam Mendirikan UMKM Dan Efektivitas Promosi Melalui Online Di Kota Tangerang Selatan. Jurnal Ilmiah MEA (Manajemen, Ekonomi, \& Akuntansi), 4(3), 702-714. https://doi.org/10.31955/mea.vol4.iss3.pp702714

Lukiastuti, Fitri, et.al (2020). The Influence of Entrepreneur's Personal Characteristics on SMES Performance Mediated by Entrepreneurial Orientation. International Journal of Psychosocial Rehabilitation. Volume 24 - Issue 8

Primiana, I. (2015). Peningkatan Daya Saing UMKM Jawa Barat dalam Menopang Perekonomian Nasional Menghadapi Persaingan Global ditinjau dari sisi Supply Chain. Bandung: Fakultas Ekonomi dan Bisnis Universitas Padjajaran.

Robbins, S. P. (2013). Organizational Behavior. New Jersey: Pearson Education.

Sunarsi, D. (2020). The Influence of Supply Chain Strategy on Employee Performance on Small and Medium Business in Beringharjo Market, Yogyakarta- Indonesia. International Journal of Supply Chain Management. Vol. 9, No. 5.

\section{Website :}

http://www.depkop.go.id/data-umkm. Perkembangan Data Usaha Mikro, Kecil, Menengah (UMKM) dan Usaha Besar(UB) Tahun 2017 - 2018, diakses 24 Agustus 2020 pukul 14.00.

http://www.depkop.go.id/uploads/tx_rtgfiles/04._Paparan_Rakornas_Yogyakarta_ 2018_-_Jawa_Barat.pdf, diakses 24 Agustus 2020 pukul 14.35.

https://www.bappenas.go.id/files/1814/2057/0437/RPJP_2005-2025.pdf, diakses 24 Agustus 2020 pukul 14.25. 